\title{
Da religiosidade: entre místicos, bestas e soberanos
}

Rafael Alonso

UFSC

\section{Resumo}

Levando em conta o que aqui se chama "crise da religiosidade", este ensaio se propõe a discutir, em contraposição crítica que a leitura do texto tende a tornar evidente, as respostas a essa crise oferecidas por Georges Bataille ("experiência interior", "experiência do sagrado") e Giorgio Agamben ("altíssima pobreza”). O que motiva a contraposição é o juízo de Agamben a respeito de Bataille, antes já enunciado por Sartre: o de que Bataille é um místico. Para colocar em prática essa operação, este ensaio recorre às contribuições de Jean-Luc Nancy (existência “insacrificável”), Jacques Derrida (o discurso político como fábula e a crítica feroz a Agamben em "A besta e o soberano") e Vilém Flusser, base teórica que atravessa todo ensaio e que, com o conceito de "instrumento", mas também a partir de outras elaborações teóricas, permite questionar a ideia de um mundo a ser "profanado".

Palavras-chave: religiosidade; místico; soberania; instrumento; Flusser.

\begin{abstract}
This paper aims to discuss, as well as to put in critical opposition, what is hereby named "crisis of religiosity" and the responses to such crisis stated by Georges Bataille ("inner experience", "experience of the sacred") and Giorgio Agamben ("the highest poverty"). What moves this opposition is Agamben's judgment of Bataille, already enunciated by Jean-Paul Sartre: that Bataille is a mystic. In order to put this operation into practice, this paper reaches for the contributions of Jean-Luc Nancy ("never-to-be-sacrificed existence"), Jacques Derrida (the political discourse as a fable, as well as the harsh criticism to Agamben in "The beast and the sovereign") and Vilém Flusser, theoretical foundation of this discussion that, with the concept on "instrument", as well as with other elaborations, allows the questioning of the idea of a world to be "profaned".
\end{abstract}

Keywords: religiosity; mystic; sovereignty; instrument; Flusser. 
1. BENJAMIN, Walter.

"Experiência e pobreza", 1994, p. 115.

2. “O tédio é o pássaro de sonho que choca os ovos da experiência". BENJAMIN, Walter. "O narrador.

Considerações sobre a obra de Nikolai Leskov", 1994, p. 204.

3. Idem. "Experiência e pobreza", 1994, p. 118.

4. FLUSSER, Vilém. "Da religiosidade”, 2002, p. 16.

5. Ibidem, p. 16.

6. Idem. "Ser judeu", 2014, p. 121.

7. Idem. "Da religiosidade", 2002, p. 19.
Em ensaio deveras conhecido, publicado em 1933 sob o título de "Experiência e Pobreza", Walter Benjamin assinala: "Porque não é uma renovação autêntica que está em jogo, e sim uma galvanização"1. Galvanizar, em significado retirado do dicionário, denota eletrizar, excitar, reanimar, dar vida a. Também significa dar um banho de zinco - em peças metálicas - a fim de evitar a oxidação ou garantir maior durabilidade. Neste sentido, galvanizar a experiência significa reanimá-la, retirá-la da inércia e impedir que ela se atrofie. Trata-se de recuperá-la, de trazê-la à vida, não de enterrá-la - ela não morreu, no máximo está $\mathrm{em}$ vias de ou em extinção. Galvanizar implica processo de reenergização de superfícies metálicas por meio de corrente elétrica. Superfícies metálicas são excelentes condutores. Do que se trata, portanto, é de chocar ${ }^{2}$ uma outra experiência. Daí estarmos, conforme Benjamin afirma no mesmo ensaio, dentro de uma nova, e desta vez positiva, barbárie. Antes de sair à caça de novas experiências, o homem quer se libertar de toda experiência e, ostentando sua pobreza interna e externa, descobrir se "algo de decente possa resultar disso"3.

Vilém Flusser chama a capacidade comum a todos os homens de captar a dimensão sacra do mundo de "religiosidade"4. Do ponto de vista não-transcendental, a única via de acesso a essa religiosidade é o que filósofo considera a "vivência interna"5. A capacidade religiosa torna o mundo opaco, profundo e problematiza a morte. Ela deixa obscura a visão antes clara do mundo. Ocorre que a pouca capacidade para o sacro e o profundo, ainda mais numa época dominada pela superficialidade das imagens técnicas, expõe a crise da religiosidade: há alguns, diz Flusser, que optam pela clareza e abafam dentro de si a voz da religiosidade; há outros que sabem que a clareza é chata, e assim fingem um sentimento religioso para o qual não tem capacidade, enganando a si mesmos. É por isso que Flusser desconfia das "conversões" em voga: "não se pode deliberar o absurdo"

O problema da religiosidade no Ocidente resume-se, para Flusser, ao seguinte aspecto: está limitado à realização de um único projeto. Até sabe intelectualmente de outras formas de religiosidade, mas as tentativas de tradução estão fadadas ao malogro da inautenticidade. Segundo Flusser, o Ocidente está preso às grades da revelação sinaica. "O sacro é, para nós, exclusivamente Deus. [...] É esse o projeto dentro do qual fomos jogados e é essa, no fundo, nossa definição de ocidentais dentro da qual existimos"7. A religiosidade do Ocidente é absurda, pois pede fidelidade ao significado transcendente do mundo mesmo diante de toda evidência em contrário.

A crise se mostra de modo mais claro no fim do século XIX, com o estabelecimento definitivo da ciência moderna, embora o Iluminismo já tenha, em sua base, "conceitos 
para-religiosos" "como razão e natureza. A tecnologia atual, segue Flusser, parece recair em "profanação total e enfadonha". Isso sem contar as guerras religiosas, que marcam o começo da Idade Moderna. Diante disso, as religiões tradicionais tornam-se inaceitáveis. Já as que Flusser considera exóticas são tomadas como fugas. O desvio da religiosidade na direção da política, da economia e da tecnologia decepciona. Invejam-se os crentes tradicionais e os que se satisfazem com formas substitutas de religião na mesma medida em que se os despreza. "Essa mistura de inveja e desprezo, de humildade e blasfêmia, caracteriza a religiosidade insatisfeita. É essa religiosidade não comprometida e portanto faminta de compromisso que construirá, a meu ver, o futuro" ${ }^{\prime 10}$.

$\mathrm{O}$ que Flusser parece afirmar é que o mundo iluminado e transparente da ciência é insuportável. O homem precisa do opaco, do mistério. Em um de seus textos, Flusser marca nesse ponto a diferença entre resolver problemas - trabalho da ciência que opõe sujeito e objeto, e que não deixa resto - e solucionar enigmas, processo que deixa resto, um significado ${ }^{11}$. No entanto, as formas tradicionais de captar a dimensão sacra do mundo, ou de perceber a opacidade do mundo, estão decaídas, bem como o canal de ligação com o transcendente, chamemo-lo de Deus ou não, mostra-se definitivamente rompido.

Ou seja, tanto a iluminação divina das religiões tradicionais quanto a iluminação profana da ciência e da tecnologia não são capazes de, nos termos de Benjamin, "chocar" uma experiência autêntica. Depois dos efeitos catastróficos das duas grandes guerras, depositar confiança em Deus ou na ciência moderna torna-se praticamente impossível. Além do mais, já são conhecidas as consequências desastrosas que podem resultar da evolução da ciência e da aplicação da técnica. Theodor Adorno e Horkheimer fazem essa advertência quando criticam o aspecto desencantador do mundo da ciência em $A$ dialética do esclarecimento. Flusser aponta para uma direção análoga quando considera algumas das iniciativas da ciência como "para-religiosas". Aliás, a substituição da crença religiosa pela crença na ciência, ou a transformação da ciência em religião, já estão identificadas em grande parte dos livros de Nietzsche, em especial em $A$ gaia ciência. O pensador alemão ataca até mesmo os ateus convictos, já que o ateu, antes de negar a existência de Deus, ou, ainda, ao negá-la, precisa paradoxalmente afirmá-la.

Não foram poucos os pensadores que ao longo do século XX falaram em crise da religião, crise da experiência ou em experiência fragmentada. Para ficar na linha dos judeus que se atraíram pelo pensamento a respeito das imagens técnicas, como Benjamin e Flusser, pode-se lembrar de Siegfried Kracauer, que também trata da crise da ciência e da experiência desmembrada da classe média alemã do entre - e do pós-guerra - em obras
8. Ibidem, p. 20

9. Ibidem, p. 20

10. Ibidem, p. 21.

11. Idem. "Livros", 1998, p. 127. 
12. ELIADE, Mircea. O sagrado e o profano, 2008, p. 165. como O ornamento da massa e Os empregados. O que está em questão é localizar no intervalo - intervalo que também constitui as imagens técnicas - um lugar possível entre a opacidade excessiva da religião e a clareza excessiva da ciência moderna. Nas palavras de Benjamin, trata-se de chocar outra experiência em meio à barbárie. Nas palavras de Flusser, trata-se de forjar um tipo de "vivência interna" que mantenha o mistério a salvo, mas que para isso não recorra a Deus.

No campo dos estudos propriamente religiosos, pode-se citar o conhecido livro de Mircea Eliade, O sagrado e o profano, publicado em 1957. Eliade assinala que a marca da experiência do homem moderno é a completa dessacralização, ou seja, o homem moderno só pode viver autenticamente se estiver liberto de tudo que possa remeter ao sagrado. Isso torna a sua experiência trágica, ainda que provida de grandeza. "O sagrado é o obstáculo por excelência à sua liberdade. O homem só se tornará ele próprio quando estiver radicalmente desmistificado. Só será verdadeiramente livre quando tiver matado o último Deus" ${ }^{2}$. Segundo Eliade, o homem contemporâneo, embora não consiga reeditar a religiosidade arcaica, tem dificuldade de se ver completamente livre dela. Assim, por mais que se diga a-religioso, o homem opera religiosamente durante alguns dos ritos modernos, como o casamento, a valorização da casa própria (lar), etc. Eliade reconhece, assim, que a crise que põe em questão a realidade do mundo e a presença do homem nele é religiosa. No entanto, durante todo o livro Eliade tem dificuldade em separar quase cartesianamente o sagrado do profano, na tentativa de trazer à tona o homem integralmente profano. Essa dificuldade reforça a crise de religiosidade aqui exposta a partir de Vilém Flusser.

Este ensaio parte, portanto, dessa crise, no sentido em que o benjaminiano Flusser a concebe, ou seja, como "vivência interna" - em seu aspecto individual. Em seguida, postula que dois pensadores importantes do século XX, um deles ainda vivo, Georges Bataille e Giorgio Agamben, identificaram essa crise, mas responderam a ela de modo diverso. A proposta deste ensaio é analisar, em contraposição crítica que ficará evidente, a resposta de cada um. É evidente que Bataille e Agamben não pensaram o problema nos mesmos termos de Flusser. Mas a aposta deste ensaio é que ambos trataram do mesmo problema nas obras que serão citadas. Já nas primeiras de suas obras, como em Infância e história, Agamben fala de uma experiência decaída. Bataille, aflito entre os bombardeios da guerra, obstina-se por pensar uma "experiência interior", uma "experiência do sagrado". Ambos parecem atentos ao fato de ser difícil ao homem viver numa espécie de imanência absoluta. Ao mesmo tempo, o caminho em direção a Deus parece vedado. A proposta, portanto, sugere que o problema da "crise da religiosidade" 
levantado por Flusser foi também pensado por Bataille e Agamben. O objetivo é expor criticamente os caminhos percorridos pelos dois diante desse problema. Para tanto, o ensaio se valerá das contribuições de Nancy sobre o sacrifício e das elaborações teóricas de Derrida sobre a soberania, já que supor uma fratura na "vivência interna" do homem ou na sua capacidade para a religiosidade implica pensar possíveis modelos de soberania. A leitura do ensaio tornará claro que Flusser opera tanto como objeto de discussão quanto como referência metodológica.

Mas, antes de pormenorizar ambas as posições, convém refletir sobre um juízo crítico de Jean-Paul Sartre a respeito de Bataille, compartilhado por Agamben. Vale dizer que Bataille morre em 1962, portanto oito anos antes que Agamben desse início à publicação em livro de seus conteúdos. Sobre Agamben, Bataille nunca emitiu uma palavra. Por outro lado, Agamben compartilha com Sartre o seguinte veredicto sobre Bataille: é um místico. Sartre intitula sua resenha de "A experiência interior", publicada em 1943, com o título: "Um novo místico". Agamben, por sua vez, assinala que Bataille faz parte de uma "tradição mística" 13 de pensamento, além de repetir com ênfase a opinião de Benjamin sobre as atividades do grupo Acéfhale e das ideias expostas em "Noção de dispêndio": "Vous travaillez pour le fascisme!". Desta forma, uma das perguntas que motiva este ensaio é: por que, para Agamben e Sartre, Bataille é um místico?

Uma passada breve por Sartre, já que um dos objetivos específicos deste ensaio é contrapor Agamben a Bataille. Em resumidas palavras, pode-se dizer que, para Sartre, Bataille substitui Deus por um conceito essencialista de não-saber. $\mathrm{O}$ não-saber é seu transcendente. Se por um lado Bataille avança em direção aos limites do saber, por outro falseia essa tentativa na medida em que dá a esse espaço em branco, não dominado pelo saber, o nome de não-saber. Critica a racionalidade conceitual em nome de outro conceito, que para Sartre é vago e se traveste de palavras polpudas, tais como noite, escuridão, treva, etc.

Para Sartre, a teoria de Bataille, se é que ele teria se preocupado em elaborar uma, gira no vazio. Bataille substantifica a própria ignorância, são as palavras de Sartre. Ou seja, diz que nada sabe e, a essa ignorância, dá o nome de não-saber, positiva o desconhecido. Se o não-saber é o saber, o saber que é o não-saber se perde, e volta a ser não-saber. "É realmente um místico que fala, um místico que viu Deus e que rejeita a linguagem demasiado humana daqueles que não o viram"14. A ausência de projeto e de um sistema filosófico consistente deixa em Sartre a sensação de que Bataille põe em prática um palavreado inútil recheado de adjetivos:
13. AGAMBEN, Giorgio.

"Bataille e o paradoxo da soberania". outra travessia, n. 5 , 2005, p. 92.

14. SARTRE, Jean-Paul apud. BATAILLE, Georges. Sobre Nietzsche, p. 218, no prelo. Agradeço à generosidade do tradutor Fernando Scheibe que permitiu a mim, enquanto estudante de pós-graduação, que lesse e citasse a tradução ao português da Suma Ateológica, ainda inédita. A indicação das páginas da "Suma" referidas aqui me foram passadas pelo próprio Scheibe. A publicação da "Suma" está prevista para junho, pela editora Autêntica. 
15. Idem. p. 221.

16. FLUSSER, Vilém. Gestos, 2014.

17. BATAILLE, Georges. Sobre Nietzsche, p. 217, no prelo.

18. Ibidem, p. 217.
As alegrias, diz ele, a que nos convida o Sr. Bataille, se não devem remeter mais do que a si mesmas, se não devem se inserir na trama de novos empreendimentos, contribuir para formar uma humanidade nova que se superará em direção a novas metas, não valem mais do que o prazer de beber um copo de vinho ou de se aquecer ao sol numa praia ${ }^{15}$.

Definitivamente, o dispêndio improdutivo não deveria ser um dos passatempos favoritos de Sartre. Ao menos quando o assunto é a filosofia. De qualquer jeito, se há alguma meta na vida que valha mais a pena de se engajar do que o gesto prazeroso (aos que bebem) de tomar um gole de cachaça, é algo que fica em aberto. Toda alegria encerrada em si mesma, que não dê sequência a esse projeto humanista mal esboçado nesse parágrafo, não faz sentido a Sartre. Torna-se realmente fácil imaginar, a partir destas poucas linhas, a que nível de consideração Sartre mantém as "teorias" batallianas do riso, do gozo, da embriaguez. Para Flusser, todo gesto ${ }^{16}$ humano tem aspecto absurdo e, no limite, é encerrado em si mesmo. Como o gesto de fumar cachimbo, do qual o filósofo era um adepto compulsivo. Apesar de encerrado em si mesmo, o gesto humano, tanto para Bataille como para Flusser, tem caráter ritual, ou seja, o fato de encerrar-se em si mesmo não significa esvaziado de sentido.

A resposta de Bataille é respeitosa, mas devastadora. No fundo, ele admite que a leitura sartreana de seu livro não está equivocada. Apenas o desespero a que ela conduz não é suportado por Sartre. A primeira frase do texto de Bataille é definitiva: "O que desorienta em minha maneira de escrever é a seriedade que engana todo mundo"17. Bataille não julga a seriedade de Sartre como mentirosa, mas a ironiza ao dizer que toda seriedade tende a culminar na hilaridade. "Expressa sem desvios, uma mobilidade grande demais dos conceitos e dos sentimentos (dos estados de espírito) não deixa ao leitor mais lento a possibilidade de apreender (de fixar)"18. Sartre, a quem conceitos devem ser fixados, não se fixa ao texto de Bataille, e o descarta.

$\mathrm{E}$ quanto a Agamben? Por que Bataille se insere, para o filósofo, numa "tradição mística"? Em resumidas palavras, também, já que interessa a este ensaio avançar, na sequência, pelas posições de Agamben e Bataille sobre a crise da religiosidade: Agamben se mostra aflito quanto ao fato de Bataille imaginar uma comunidade em sentido negativo, ou seja, comunidade da qual os membros estão ausentes enquanto sujeitos constituídos. Tal comunidade é acéfala. Não apenas porque a cabeça racional está cortada, mas porque os próprios membros estão excluídos. Essa comunidade, prossegue Agamben, está baseada na ideia do êxtase no sentido de ek-stasis. O sujeito do êxtase é aquele que está fora-de-si no momento da experiência, e portanto não 
pode dela usufruir"19. "O paradoxo do êxtase batalliano é, na realidade, que o sujeito deve estar lá onde não pode estar, ou vice-versa, que ele deve faltar lá onde deve estar presente" ${ }^{20}$. A ideia de uma comunidade dos amantes, ou dos amigos, ou dos artistas, aqui e ali evocada por Bataille, também não convence Agamben. Experiência que não tenha sujeito não é experiência. E quem afirma o contrário é místico.

Se os caminhos para os quais aponta o pensamento de Bataille são místicos (na opinião de Agamben e Sartre) - e estes caminhos serão esmiuçados adiante -, quais são os caminhos para os quais aponta o pensamento de Agamben? Na linha de reflexão que este ensaio propõe, com que argumentos Agamben responde a essa crise de religiosidade? Esses argumentos serão perseguidos especialmente a partir de duas obras recentes do filósofo, e que compõe o conjunto Homo Sacer, Altíssima Pobreza e Opus Dei. Mas antes de esmiuçar os argumentos de Agamben nestes dois trabalhos, convém gastar algumas linhas sobre o modo como, para o filósofo, opera o direito.

O que permite o funcionamento do direito é a exceção. $\mathrm{Na}$ medida em que a norma jurídica está ligada antinomicamente à sua aplicação, toda sanção jurídica que resolva ser posta em prática exige a exceção. $O$ código jurídico não tem uma relação de identidade com a vida corrente, portanto toda aplicação do direito demanda, em maior ou menor grau, violência. Para Agamben, a história do Ocidente é marcada pela juridicalização da vida, ou seja, pela passagem do espaço religioso para o espaço do direito, ou ainda, pela transformação de toda zoé em biós.

A vida qualificada, biós, em Agamben, é a vida capturada pelo direito. A essa violência demandada pelo direito em sua aplicação Agamben dá o nome de soberana. Isso porque a posição do soberano é perfeitamente adequada para o exercício desta violência: ela se encontra ao mesmo tempo dentro e fora do direito. O soberano tem a condição de, "legalmente", desvalidar a lei. "O soberano é o ponto de indiferença entre violência e direito, o limiar em que a violência transpassa em direito e o direito em violência" ${ }^{21}$. Já o messias do pensamento judaico-cristão, para Agamben, seria uma espécie de soberano paz-e-amor: ele tem a mesma prerrogativa para desvalidar a lei, mas desta vez para salvar a humanidade, e não para conduzi-la ao campo de extermínio.

Depreende-se, assim, que o homem, para Agamben, é cindido pelo direito. A crise religiosa, em Agamben, é também uma crise do direito. Mas essa cisão funciona como ponto disparador para uma reflexão ética mais profunda. Como imaginar um homem não-cindido pelo direito? Como imaginar uma forma-de-vida dentro da qual coincidam norma e aplicação? Mais radicalmente: existe alguma possível forma-de-vida que
19. Valeria a pena indagar se as experiências vividas sob efeito de álcool ou de drogas tem, ou não, validade para Agamben.

20. AGAMBEN, Giorgio.

"Bataille e o paradoxo da soberania". outra travessia, n. 5 , 2005, p. 92.

21. Idem. Homo sacer: o poder soberano e a vida nua, 2002, p. 38. 
22. Idem. Altissima pobreza, 2014, p. 116.

23. Ibidem, p. 43.

24. Ibidem, p. 64.

25. COCCIA, Emanuele.

"O mito da biografia ou sobre a impossibilidade da teologia política". outra travessia, n. 12 , 2012, p. 7-21.

26. AGAMBEN, Giorgio. Opus Dei, 2013, p. 65.

27. Ibidem, p. 9. não se deixe capturar pelo direito ou, na melhor das hipóteses, uma forma-de-vida na qual a fusão entre norma e aplicação seja tal que não permita que se exerça a violência do direito?

Foi dito que a teoria de Agamben transita da religião em direção ao direito. Porém, em qual espaço encontra-se, para Agamben, a possibilidade de uma forma-de-vida dentro da qual norma e aplicação coincidam? Justamente no espaço religioso, mais precisamente entre os franciscanos. À parte a ideia de usus facti defendida pelos seguidores de São Francisco de Assis, e que remete a um uso desprovido de propriedade e que compõe a proposta franciscana do voto de pobreza, ideia esta que deveria, ou poderia, ser observada mais de perto, Agamben define o franciscanismo como a "tentativa de realizar uma vida e uma prática humanas absolutamente fora das determinacōoes do direito"22. Agamben afirma que o monge franciscano obedece a preceitos que "se assemelham mais às regras de uma arte do que a um dispositivo legal"23. Neste sentido, Agamben sustenta que o mandamento cristão não está pautado numa natureza legal. “[...] quem promete não se obriga, como acontece no direito, ao cumprimento de atos singulares previstos na regra, mas põe em questão seu modo de viver [...]"24.

Mas por que, para Agamben, o franciscanismo se encontraria fora das determinações do direito? A resposta aparece mais claramente em Opus Dei. Cristo coincide exatamente com a liturgia. A vida de Cristo pratica (no sentido de pôr em prática) o mandamento divino. Cristo vive liturgicamente. É por isso que a Bíblia, mais do que um livro, é um manual. Todos devem viver como Cristo viveu. Já Emanuelle Coccia ${ }^{25}$ fala desse aspecto da vida de Cristo enquanto lei em formação. Isso porque a forma tradicional do direito vai do código em direção à aplicação. $\mathrm{Ou}$ se parte da aplicação, pode-se dizer que vai desta em direção à punição. No caso cristão, é como se Cristo tivesse elaborado esse código jurídico doutrinatório chamado cristianismo simplesmente vivendo a própria vida. Está-se diante de uma versão distorcida do feito/sendo do Livro de Mallarmé, de que fala Maurice Blanchot. O endeusamento midiático de certos juízes no Brasil, como Joaquim Barbosa e Sergio Moro, pode ser lido por esse viés.

Ainda com Agamben, cabe ao sacerdote (ou será que caberia a todo e qualquer ser humano?) fazer coincidir mistério e ministério. O sacerdote deve falar do mistério, mas vivê-lo também. O exemplo vem de cima. A fé cristã mobiliza a ontologia, pois sugere a transformação do ser em operatividade ${ }^{26}$. Segundo Agamben, é através do ofício que ser e praxe se indissociam, entram em uma "zona de indistinção" por meio da qual o ser se realiza em seus efeitos práticos e, em "perfeita circularidade"27, não mais separa ser e dever ser. 
Em Opus Dei, Agamben vê no ofício do sacerdote, esse ministro do mistério, a materialização de uma autêntica ontologia. Mas, se em Altíssima Pobreza o franciscanismo é uma válvula de escape ao radar implacável do direito, em Opus Dei, à página 110 da tradução brasileira, religião e direito se mostram idênticos: "Na ideia de um ser que se resolve integralmente em um débito, em um ter de ser, direito e religião coincidem necessariamente" ${ }^{\prime 28}$. No primeiro livro, a indistinção entre norma e aplicação des-cinde o sujeito e, ao coincidirem, permitem ao franciscano escapar do direito. No segundo livro, a equiparação entre norma e aplicação é, ao contrário, aquilo que aproxima direito e religião. Mas, se religião e direito estão apoiados num "ter de ser", qual a diferença entre um frade franciscano e um cidadão patriota que diz seguir as leis da constituição a fim de "construir uma nação melhor"? Se direito e religião coincidem, qual seria o privilégio ontológico dos adeptos de São Francisco? Se direito e religião coincidem, qual seria, trocando em miúdos, a especificidade ética de um sacerdote? Afinal, cristãos, franciscanos e sacerdotes estão fora do direito por viverem uma vida litúrgica ou, ao contrário, essa vida litúrgica é o que permite, subrepticiamente, ao direito retornar pela porta dos fundos? Um franciscano está mais próximo de um outsider ou de um cidadão exemplar?

O que fica claro é que diante do que este ensaio chama, apoiado em Vilém Flusser, de crise da religiosidade é respondida por Agamben através de uma perspectiva religiosa, perspectiva esta que já está exposta desde os títulos dos trabalhos citados. Agamben apresenta, em Homo Sacer I, o homem cindido pelo direito. Diante dessa cisão, recorre a exemplos, ou a formas-de-vida, que supostamente permitem superar essa cisão. E as encontra, ou parece encontrar, na religião, em especial no franciscanismo. Vale dizer que a operação por meio de oposições que formam uma cisão já aparece desde o primeiro livro de Agamben, $O$ homem sem conteúdo, por meio da fissão práxis e poiesis.

Mas é evidente que Agamben não está a propor que os homens trajem batas franciscanas, calcem sandálias de fivelas, façam voto de pobreza e saiam à rua a conversar com os pássaros. É redutor ler as duas obras citadas enquanto sistematizações de prática. Todavia, para falar com Flusser, Agamben vê no franciscanismo um "modelo", algo que se não deve ser aplicado em repetição, pode servir de base e ponto de partida a uma determinada reflexão ${ }^{29}$ ou ao que Flusser chama de "vivência interna".

Em busca de uma outra ética, de uma outra ontologia, de uma outra religiosidade, Agamben recorre aos modelos cristãos. Mas não haveria, aí, um preço a se pagar? Propor a "altíssima pobreza" como modelo ontológico não é incluir toda uma carga castradora que, se resolve o problema por um lado, complica-o por outro? Os altos e pobres não são, ainda assim, cristãos? O führer também não faz coincidir em seu corpo e vida, de
28. Ibidem, p. 110.

29. É ao caráter de modelo do judaísmo que Flusser atribui grande parte do antissemitismo, já que todo modelo traz em si um aspecto impositivo que tende a suscitar reações raivosas. Para Flusser, o que caracteriza o judaísmo é o que Agamben chama de liturgia, ou seja, uma vida inseparável do ritual. Mas as deduções críticas de ambos, a partir daí, são bastante diferentes. 
30. BATAILLE, Georges. O erotismo, p. 56.

31. Ibidem, p. 35.

32. FLUSSER, Vilém, "Ensaios", 1998, p. 93-97.

33. BATAILLE, Georges, O erotismo, 2013, p. 111. certa forma, liturgia e ontologia? Será que um SS não vive liturgicamente? $\mathrm{O}$ funcionário pode ser padrão, mas a que lógica ele responde? Quem trabalha mais para o fascismo, um membro da seita acéfala ou um membro da seita franciscana? $\mathrm{O}$ trabalho de Agamben, como se disse, caminha da religião em direção ao direito. Mas, quando faz a crítica do direito, o filósofo retorna à religião. Seria o caso de recorrer a um modelo que fugisse tanto do direito quanto da religião? Tal modelo existe? É vivível? O modelo que oferece Agamben, se escapa ao direito, exige como contrapartida o dobrar dos joelhos.

É momento de passear pelos pressupostos de Bataille a respeito do assunto. Não é equivocado afirmar que a questão central no pensamento de Bataille é a religião, ou melhor dito, a religiosidade, nos termos em que ela se define aqui, como "vivência interna". Interessa a Bataille uma determinada experiência que permita fugir da banalidade contemporânea sem apelar à transcendência. Uma experiência que tangencie os limites estabelecidos pelo não-absoluto, a morte. Em $O$ erotismo, ele afirma que seu problema se assemelha ao do teólogo, à diferença de que não pretende se deter em uma religião, o cristianismo ou qualquer outra, mas à religião em si - este trabalho acrescentaria, nos termos de Flusser, à religiosidade. "Não falo nem de ritos, nem de dogmas, nem de uma comunidade determinados, mas somente do problema que toda religião se colocou: faço meu esse problema como o teólogo faz da teologia o seu" 30 .

Bataille reconhece no cristianismo uma forma possível de religiosidade. E é neste sentido que o cristianismo lhe interessa, como forma de religiosidade, não por acaso a mais recorrente no Ocidente. O que ocorre é que Bataille desacredita da "vivência interna" sugerida pelo cristianismo. Desconfia da autenticidade dos seus ritos. A leitura de qualquer texto de Bataille, ou até mesmo uma passada de olhos por seus traços biográficos, mostra a relevância que ele atribuía à seriedade de todo rito que perpasse a existência. Um ritual autêntico deve implicar a vida de quem dele participa. "Do erotismo, é possível dizer que é a aprovação da vida até na morte" ${ }^{31}$. Motivos análogos levaram Flusser a desprezar o pensamento que ele chama de "acadêmico" 32 . O ritual acadêmico, para Flusser, e o ritual cristão, para Bataille, são fingidos. "Os cristãos nunca conheceram outro sacrifício que não o simbólico"33.

Mesmo nos casos em que o ritual cristão é eventualmente subvertido, e através de algum membro interno (um devoto), essa subversão é posta em dúvida por Bataille. Exemplo emblemático é o de Santa Tereza. Uma leitura atenta das passagens que Bataille dedica à santa em $O$ erotismo permite concluir que Tereza, se não tem um êxtase fingido, tampouco goza efetivamente. É como se Tereza chegasse ao limiar, ao ponto em que 
teria de decidir entregar-se à experiência profana do gozo e do êxtase ou recuar e se manter fiel à vida casta.

Tomada pela culpa, ela recua, como dá a entender Bataille. A expressão extasiada de Santa Tereza não é fruto de gozo profano, mas de lamentação culpada. Duplamente culpada: primeiro, porque não se entrega a um gozo que sabe prazeroso; segundo, porque mesmo ao não se entregar reconhece, no ato da negação, a delícia da qual abre mão. Se a religião cristã tende a culpabilizar até pensamentos que julga pecaminosos, Tereza peca, e peca duas vezes. Sua expressão, portanto, pode ser considerada de sofrimento, e não de êxtase, pois escolhe permanecer numa castidade que não lhe completa, e ao mesmo tempo lamenta não poder se entregar ao gozo profano. Frente ao limiar, Tereza não faz nem uma coisa, nem outra, e quem sabe sua angústia provenha justamente da incapacidade de sair de cima do muro. A imagem de Tereza é a mesma do cervejeiro que foge do boteco porque trabalha no dia seguinte pela manhã: se for para tomar apenas uma, ele prefere nem molhar o bico. Ao contrário de Agamben, que não parece mensurar as consequências da assunção de uma liturgia cristã como pressuposto ontológico, Bataille refuta o ritual cristão mesmo em suas formas eventualmente desviadas.

Não é, de fato, simples sondar um tipo de experiência que possa ser considerada sagrada - palavra recorrente nos textos de Bataille - e que, ao mesmo tempo, abra mão da transcendência divina. Difícil, também, é não tomar como religiosos, no momento da leitura crítica, textos que empregam em suas elaborações teóricas conceitos e expressões marcadamente religiosos. É por isso que esse trabalho postula que falar de religiosidade, enquanto "vivência interna", é diferente de falar de religião. Assim como Flusser postula que admitir que o homem carece de religiosidade não significa dizer que ele precisa de Deus.

No caso das "propostas" batallianas, elas se tornam dificilmente digeríveis pois se apoiam em experiências efêmeras. A experiência do gozo, do riso ou da embriaguez, em Bataille, não leva à afirmação de uma subjetividade, mas ao implicar o que o homem possa ter de mais próprio, o desapropria de toda essência. A ideia de um dispêndio improdutivo, do gasto pelo gasto, não leva a lugar nenhum, o que certamente contraria pensadores preocupados com a elaboração de sistemas filosóficos consistentes como Sartre e Agamben. Sobre a literatura, por exemplo, Bataille afirma que ela, ao por em jogo o essencial do homem, não pode ser útil, já que o essencial do e no homem não é redutível à utilidade ${ }^{34}$.

Especialmente em $A$ experiência interior, livro resenhado por Sartre, Bataille recorre inúmeras vezes ao termo "místico". Mas não o faz para advogar em favor de uma experiência mística,
34. Idem. "Es útil la literatura?", 2001, p. 17-19. 
35. Idem. A experiência interior, p. 29, no prelo.

36. Idem. O culpado, p. 29, no prelo.

37. Idem. Lo que entiendo por soberania, 1996, p. 105.

38. Idem. "El erotismo o el cuestionamiento del ser", 2001, p. 349. mas justamente para apontar o que diferencia a experiência que ele propõe como "interior" da experiência mística. Uma passagem esclarecedora:

Entendo por experiência interior aquilo que se nomeia habitualmente experiência mística: os estados de êxtase, de arrebatamento, ou ao menos de emoção meditada. Mas penso menos na experiência confessional, a que os místicos se ativeram até aqui, do que numa experiência nua, livre de amarras, e mesmo de origem, que a prendam a qualquer confissão que seja. É por isso que não gosto da palavra mística. ${ }^{35}$

O que incomoda Bataille em toda experiência mística é que ela está fundada na crença do valor revelador do êxtase. É como se no auge da excitação um pensamento edificante devesse sobrevir - a visão de Deus. Em tempo: qual é a exigência de Agamben quando critica o êxtase batalliano na medida em que, no momento do êxtase, o sujeito encontra-se ek-staziado, ou seja, fora-de-si? Pensar uma forma de êxtase que, no cume, permita ao sujeito manter o controle sobre si mesmo não é projetar uma forma reveladora de êxtase? Lembre-se que esse, para Agamben, era o "paradoxo" da soberania em Bataille, ou seja, como pode o sujeito considerar-se soberano se, no momento de afirmar a própria soberania, ele está ausente? Cabe pensar, no entanto, se a soberania para Bataille não é justamente o esvaziamento deste sujeito constituído em nome de uma comunhão, imanente, e não mística, com e no outro. Não é isso que Bataille quer dizer quando afirma categoricamente que a soberania não é nada? Ou será que Agamben imagina repetir o gesto de Benjamin que, ao experimentar o haxixe, pede ao amigo que lhe acompanha que se mantenha sóbrio a fim de anotar as "iluminações" que o efeito da droga faria advir?

Bataille sugere o contrário: não uma experiência em que um dos envolvidos se mantenha de olhos abertos a fim de anotar os "resultados" da experiência (ideia que faria pensar em experimento, e não em experiência, por mais que tal experimento não tivesse a intenção de comprovar nada), mas uma experiência que funda - no sentido de fundir -, imanentemente, corpos descontínuos. A experiência erótica passa por aqui. Já em $O$ culpado, Bataille resume a problemática em uma frase: "A experiência mística difere da erótica por ter um êxito pleno"36. O aspecto desconcertante da soberania, em Bataille, localiza-se neste ponto: a possibilidade dada a qualquer homem de perceber sua verdade interior no outro e a dificuldade que tem em percebê-la em si mesmo ${ }^{37}$. Na vida erótica, o sujeito se consome ao invés de se edificar.

A vida erótica, assim como a vida religiosa, é de natureza espiritual. A experiência interior exige "sensibilidade religiosa"38, 
que conjuga desejo e horror, prazer intenso e angústia, medo de romper a proibição e desejo de transgredi-la. Mas, para Bataille, nós não temos necessidade alguma de religião, já que o mundo está impregnado de sagrado. O que falta ao mundo atual é propor tentações ${ }^{39}$. Mas tais tentações não oferecem respostas convincentes a esse mundo que assume o capitalismo como religião ${ }^{40}$. Não oferecem do ponto de vista de uma resposta produtiva a um mundo produtivo. É por isso que a experiência de Bataille está baseada no não-saber. Não para responder misticamente e positivar o "nada", mas para tornar improdutivo o domínio do saber racional. Soberanos para Bataille são os raros momentos em que o homem age não tendo em vista um fim utilitário. Ainda que existam resquícios de experiência religiosa nesta experiência do não-saber, elas estão desvinculadas da preocupação com o porvir e separadas de um sofrimento ameaçador que as governe, não sendo mais que um jogo ${ }^{41}$.

De volta a $O$ erotismo, há uma passagem em que Bataille esclarece com precisão que seu trabalho não é o de positivar o nada ou o substancializar a própria ignorância, nem o de acrescentar ao vasto conjunto do saber um outro saber, desta vez negativo. "Não falo do nada, que me parece por vezes um pretexto para acrescentar ao discurso um capítulo especializado, mas da supressão daquilo que a linguagem acrescenta ao mundo" ${ }^{42}$.

Este é um ponto do pensamento de Bataille que merece ser comentado. Bataille não se cansa de criticar a falibilidade do pensamento racional e filosófico bem como a falta de competência da linguagem para articular o que ele chama de "experiência interior" e de "experiência do não-saber". Da mesma forma, repetiu à exaustão que sua preocupação não era a de elaborar um "projeto" de pensamento sistemático e que sua maneira de pensar se diferenciava radicalmente dos métodos objetivos e científicos de pensamento. Em resumidas contas, não é exagero caracterizar Bataille, em sentido positivo, como anti- acadêmico. Ainda assim, em diversos de seus artigos ele próprio não deixa de fazer certa mea culpa em função de, apesar da dificuldade de articular o inarticulável, seguir o processo incessante de escrita. Com seus problemas e defeitos, a escrita pode não ter sido a maneira mais eficaz que encontrou para viver as experiências prazerosas ("interiores"), mas foi o modo mais eficiente que encontrou para articulá-las - para gritá-las e lançá-las ao mundo. O esforço constante de Bataille foi o de articular uma experiência que não se deixa apreender, ou ainda, o de pensar o que escapa ao pensamento. Com Jean-Luc Nancy, pode-se dizer que a "experiência interior" não comporta uma escrita, mas uma ex-crita. Neste sentido, o não-saber não significa a refutação de todo saber em nome de uma essencialização mística, como acredita Sartre. Trata-se, pelo contrário, de levar o saber constituído até o extremo, e de fazê-lo ruir.
39. Idem. "La guerra y la filosofía de lo sagrado", 2001, p. 157-171.

40. BENJAMIN, Walter. $O$ capitalismo como religião, 2013.

41. BATAILLE, Georges. "Nosaber, risa y lágrimas”, 2002 , p. 113-134.

42. Idem. O erotismo, 2013, p. 290 . 
43. Idem. A experiência interior, p. 104, no prelo.

44. ANTELO, Raul. "O lugar do erotismo”, 2014, p. 24.
No que diz respeito à articulação de uma experiência em si inarticulável (como falar do gozo, do riso ou da embriaguez?), Bataille reforça que toda experiência autêntica deve ser dramatizada. Os rituais que interessam a Bataille estão atravessados pela encenação e pelo performático. Quando critica o êxtase místico, por vir acompanhado de uma revelação, ele acrescenta: "pelo contrário, é preciso vê-lo [o êxtase] como uma ficção, como análogo, em certo sentido, às intuições da arte"43. Sobre a poesia, no mesmo livro, Bataille afirma que ela não passa de uma evocação, podendo mudar tão somente a ordem das palavras, e não o mundo. Deve ser por motivo análogo que Raul Antelo assevera, no prefácio de $O$ erotismo: "O erotismo é um mito"44. A experiência pensada por Bataille, portanto, apresenta um aspecto encenado, ficcional, que se não a falseia, também dele não pode prescindir.

Jean-Luc Nancy afirma que a questão de Bataille não é propriamente religiosa, mas a de estabelecer outro tipo de relação com o divino. Já foi dito com Bataille que ao mundo não falta o sagrado, mas tentações. No entanto, as tentações que se mostram à vista parecem ilusórias. Neste sentido, pode-se dizer que Nancy corrobora com a hipótese de que a religiosidade do Ocidente está em crise. No entanto, ao corroborar com tal hipótese, Nancy tece uma crítica - ou leva o problema mais adiante - a Bataille que não deixa de ser relevante. E o faz pela via do sacrifício.

Grosso modo, Bataille vê no sacrifício uma espécie de mediador necessário, sem o qual o "contato" com as formas imanentes do sagrado não é possível. Se não se pode efetivamente morrer durante o ritual, o sacrifício de outro ser, animal ou humano, pode permitir que se experimente a morte. Afinal, ao ritual segue-se, muitas vezes, a narrativa do ritual. Alguém deve sobreviver ao ritual para que dele se possa elaborar uma narrativa.

O ritual da tourada atrai a atenção de Bataille pelo fato de estar atravessado pela possibilidade da morte, mesmo levando-se em conta a superioridade técnica do toureiro sobre o animal. Por mais desigual que seja o duelo, o toureiro pode, sempre, morrer, embora na maioria dos casos seja o touro quem caia morto. E quem assiste à tourada não deixa de participar do ritual e de experimentar o êxtase provocado pela sensação iminente de morte, algo sobre o qual falaram Michel Leiris e o próprio Bataille. Lembre-se do quanto Bataille impressionou-se ao assistir in loco à morte do toureiro Manuel Granero, em maio de 1922, atingido em um dos olhos pelo chifre do touro. Assim, o sacrifício é tomado por Bataille como uma das formas possíveis - e mediadas - de aproximação com a experiência do sagrado. Ao contrário da experiência erótica, na qual os sujeitos envolvidos se dissolvem em favor do gozo compartilhado, que não pertence a ninguém e ao mesmo tempo pertence a ambos, 
a experiência do sacrifício demanda a participação de um vivente a ser sacrificado e mantém à certa distância aqueles que participam do ritual. Para falarmos em termos epistemológicos, o ritual do sacrifício, ao menos em sua versão ocidentalizada, exige distância crítica. Distância que se pretende seja eliminada, ou reduzida ao máximo, por meio da "aura" de morte que deve perpassar a comunidade dos participantes. Mas, para que esse sacrifício não contrarie as convicções de Bataille, ele deve ser encenado, mas não pode ser fingido ou simulado.

Nancy começa por estabelecer que o sacrifício é uma categoria ocidental e que dos sacrifícios antigos nada de concreto se pode ter conhecimento. Para o filósofo, torna-se problemático pensar o sacrifício dentro de uma tradição de pensamento que não está fundada pelo sacrifício. Por isso, para Nancy, o cúmulo do horror do século XX, o massacre dos judeus nos campos de concentração, não deve ser incluído na lógica do sacrifício. No fundo, esclarece Nancy, o que está em jogo em todo sacrifício é a passagem da mimesis em direção à methexis, ou em palavras não acadêmicas, a passagem de uma simples forma de imitação a uma forma efetiva de participação.

Mas a passagem que garante a efetividade do sacrifício em Bataille é justamente o que faz Nancy pôr em dúvida a lógica sacrificial. Segundo Nancy, a tentativa do sacrifício ocidental naufraga no percurso que leva da mimesis à methexis. Esse, para Nancy, é um problema igualmente para a arte: imitar o sangue derramado ou propor a emoção do horror real ${ }^{45}$. Como colocar a vida em jogo num ritual encenado? Ou ainda: como carregar um ritual de "vivência interna" sabendo que a vida pode até estar em jogo, mas essa vida não é a minha? Como se divertir numa festa artificial? Como se vê, a discussão em torno ao artifício, à própria ficção, não está ausente. A ela se voltará adiante.

Se Sartre e Agamben desacreditam da "experiência interior" sugerida por Bataille, Nancy desacredita da "experiência do sagrado", ao menos em sua versão sacrificial. Para Nancy, o ser está lançado no mundo e, neste sentido, é oferecido ao mundo, e não ao nada ou a ninguém. "En verdad, ni siquiera es ofrecido o sacrificado a un Nada, a ninguna cosa o a un Otro en el abismo del cual vendría todavía a gozar imposiblemente de su propia imposibilidad de ser, y es exactamente en este punto que hay que corregir, sin descanso, a Bataille y a Heidegger" ${ }^{\prime 4}$.

Nancy não emprega, em nenhum momento, o termo "místico" para definir a Bataille. No entanto, fica evidente que o sacrifício evocado por Bataille faz referência, mesmo que indireta, a um exterior do mundo, um "Afora" da finitude, algo que é rejeitado por Nancy. A leitura de Nancy atesta que o mundo, para o filósofo, se dá no contato dos corpos. Portanto, a ideia de um sacrifício, uma proposta de pensamento que leve em conta
45. NANCY, Jean-Luc. "Lo insacrificable”, 2002, p. 68.

46. Ibidem, p. 79. 
47. Ibidem, p. 79

48. DERRIDA, Jacques. Seminario La bestia y el soberano, 2010, p. 273. um sacrifício "em nome de", mesmo que esse "de" não seja Deus, é injustificável. A essa "obsessão" e a essa "fascinação" do Ocidente pelo Afora (com letra maiúscula) da finitude, a esse "desejo" de comungar com um Afora, Nancy chama de "sem fundo" e "obscuro" 47 . É sob esse argumento que Nancy considera a existência insacrificável.

A partir de Nancy, fica claro que uma crítica mais condizente ao pensamento de Bataille seria a de considerá-lo fingido, e não místico. Neste caso, a refutação batalliana de Deus poderia ser considerada falsa. Os sacrifícios elogiados por ele, simulacros não-autênticos. As próprias experiências narradas por Bataille em seus livros, muitas delas na primeira pessoa e autobiográficas, poderiam ser tomadas como narrativas ficcionais, inventadas. Por esta perspectiva, Bataille seria desenhado como um jornalista gonzo em versão literária. Esse é um risco em que Bataille incorre quando resolve transpor ao nível da linguagem escrita uma experiência que sabe intraduzível.

De certa forma, é preciso "confiar" (ter fé) de que o Bataille de espírito indomável que se apresenta em suas narrativas tenha mesmo existido. Qual seria a reação dos admiradores de Bataille diante de um biógrafo bem-informado que revelasse que, na realidade, Georges Bataille foi um funcionário público dedicado que nunca ingeriu uma gota de álcool? Ou seria o contrário, sendo esse "estilo batalliano" algo pouco interessante, e neste caso seus excessos, vividos ou imaginários, seriam perdoados em nome de sua obra de formato mais acadêmico, como é o caso de $O$ erotismo e de algumas conferências? O realmente "salvável" em Bataille encontra-se no aspecto de sua obra que ele mais refutou?

Neste sentido, o viés do misticismo não se mostra eficaz na crítica a Bataille. O golpe poderia ter mais chance de acertar o alvo caso tomasse o trabalho de Bataille como "ficção desonesta", nos termos de Jacques Derrida, que também não se furta ao assunto da soberania (Derrida usa esses termos para criticar Carl Schmidt). Por ora, o objetivo é apenas demonstrar que a crítica a Bataille pode ser mais frutífera caso se decida criticar as suas escolhas - existenciais e de escritura -, ao invés de simplesmente tomá-lo como místico e desqualificá-lo de antemão. Assumi-lo como místico soa como autodefesa precavida diante de uma escritura sabidamente potente. Para saber se o jogo de Bataille é interessante, é preciso dele participar.

Para Derrida, o mérito de Bataille foi o de ter pensado a soberania em sentido que excede à soberania clássica - domínio, senhoril, poder absoluto ${ }^{48}$. Bataille tenta pensar um tipo de soberania que escape ao modelo de soberania tradicional, ou, em outros termos, tomar a soberania a partir do baixo, e não do alto. Da mesma forma, Derrida desarma a soberania clássica ao revelar seu aspecto ficcional. Segundo Derrida, o propósito 
não é o de avaliar se num caso existe soberania e em outro não, mas o de desmontar (de dividir) uma forma de soberania que se apresenta como indivisível. Só pode haver soberania constituída, diz Derrida, onde há unidade. É preciso desconstruir a soberania a fim de apontar a base ficcional que lhe serve de apoio. Já o esforço de Agamben parece ser outro: o de mostrar como o edifício da soberania está construído de modo a permanecer inabalável. Derrida afirma que está em jogo a elaboração de outro conceito do político através da crítica à soberania dos assim chamados "estados-nações".

Não à toa Derrida escolhe o modelo fabular para questionar a soberania tradicional. Ele não deixa de apontar a ironia de, em seminário acadêmico, em nome de uma cátedra, elaborar um pensamento que escolhe a ficção como ponto de partida para criticar a política da soberania. O seminário recebe o título de "A besta e o soberano". O objetivo de Derrida é tornar claro que o poder constituído é carregado de um efeito de fábula, de narração fictícia, de simulacro. O que se apresenta como uno e indivisível assenta-se em narrativas que podem, e devem, ser tomadas sob o viés da ficção. "La soberanía es esa ficción narrativa o ese efecto de representación. La soberanía saca todo su poder, toda su potencia, es decir, toda su omnipotencia, de este efecto de simulacro [...] que le es inherente y congénito, co-originario en cierto modo" ${ }^{49}$. Essa é a vantagem da raposa sobre o leão, que mesmo sendo inferior fisicamente, sabe mentir, fingir não ser o que na verdade é.

Derrida, tendo em vista Thomas Hobbes, define o Estado como um domador de bestas por meio do medo. Essa é a lógica do Leviatã, esse "monstro marinho" ${ }^{50}$. O soberano vem para ocupar o lugar de Deus no mundo, no intervalo entre Deus e a besta - a besta é incapaz de compreender a linguagem humana, enquanto Deus não responde a chamamento nenhum. Não é possível estabelecer convenções nem com a besta e nem com Deus $^{51}$. Em nome de Deus, o soberano está apto a domesticar a besta. "A lógica do mais forte deve sempre prevalecer, como há de se provar a seguir", como estampa a fábula de La Fontaine, que serve de ponto de partida para toda a discussão de Derrida. Vilém Flusser também previne que "a transformação progressiva do cacique em La Fontaine é um aspecto da história da humanidade tão válido quanto outros mais sofisticados" ${ }^{\prime 52}$.

O ponto central da discussão aparece resumido por Derrida em forma de pergunta aos seus ouvintes logo na abertura do seminário: o que aconteceria se passássemos a tomar os discursos políticos e as ações políticas que estão a ele veiculadas como constituídos pelo fabuloso, por simulacros narrativos? O que aconteceria se passássemos a tomar o discurso político como fundado em algum como se histórico, que não se sabe direito qual, e atravessado pela lógica fabulosa do contar histórias?
49. Ibidem, p. 341.

50. Aqui caberia uma analogia com o Vampyroteuthis infernalis, de Vilém Flusser, apresentado em narrativa fabular que leva o mesmo nome. Esse monstro que habita o abismo do fundo do mar também pode servir de modelo para o questionamento da visão antropocêntrica (e soberana) do homem sobre o mundo. Isso porque Derrida deixa claro, ao falar dos "homens-lobos", que tais feras devem servir de esquema de pensamento, e não tem, necessariamente, a obrigação de estarem dotadas de uma constituição meio humana e meio bestial. Neste sentido, o vampyroteuthis poderia compor, como esquema de pensamento, o extenso conjunto de homenslobos elencado por Derrida. No mais, pelo fato de também ser uma narrativa fabular, o vampyroteuthis está apoiado no "como se" que comanda a ficção, expressão que remete ao livro de Hans Vaihinger, A filosofia do como se, de 1911, que tanto influenciou Flusser e certamente não deixou de influenciar o próprio Derrida.

51. DERRIDA, Jacques. Seminario La bestia y el soberano, 2010, p. 80.

52. FLUSSER, Vilém, "Um mundo fabuloso”, 1998, p. 24. 
53. DERRIDA, Jacques. Seminario La bestia y el soberano, 2010, p. 58.

54. Ibidem, p. 324.

55. Ibidem, p. 330.
O que aconteceria se passássemos a tomar o discurso político como uma fraudulenta máquina administrativa de "fazer saber" e que traz consigo, escondida ou escancarada, uma moral da história? ${ }^{53}$

Neste sentido, o discurso político é uma fábula bem elaborada que visa impor medo aos ouvintes e obrigá-los a seguir uma determinada moral da história. A radicalidade da crítica política de Derrida é fazer notar que o discurso político estabelecido é ficcional. A crítica não parte, como em Agamben, do próprio discurso político ou do discurso do direito, mas da ficção. Ao esmiuçar o funcionamento narrativo da fábula Derrida expõe o funcionamento fabular da narrativa política. A farsa da soberania está exposta no minúsculo rei Luís XIV que assiste in loco à autópsia de um elefante gigante, assim como está no infinitesimal das nanotecnologias e na incredulidade dos índios descritos por Montaigne diante do respeito sem sentido que uma população esfomeada mantém por um rei ridiculamente pequeno: por que não o matam?

Como já foi dito, está-se diante de três estratégias diferentes: Bataille parte em uma caça inconformada à procura de experiências outras que não as geridas pela utilidade do trabalho (gozo, riso, embriaguez); Agamben esforça-se por mostrar a magnitude do edifício do direito que nos captura desde tempos imemoriais; já Derrida afirma que esse edifício apoia-se em estrutura de base ficcional que, se trazida à tona, faz ruir o edifício. Para Derrida, não existe revolução política sem revolução poética. Neste sentido, quando se fala em soberania (ou em religiosidade, acrescenta-se) pensa-se sobre o que se pode ou não saber, e como o que se pode ou se deve saber vem a ser conhecido. A preocupação de Derrida é em desarmar o discurso político através da leitura crítica de suas narrativas. Contudo, admitir que o discurso político é uma narrativa é já familiarizá-lo ao ambiente da ficção. Uma revolução política, e também poética, visa provocar uma revolução "en el saber del saber" 54 . Trata-se de suspender a ordem e a autoridade do saber afiançado, e isto não para fazer apologia do obscurantismo ou do não-saber (não é misticismo), mas para "empezar a pensar el orden del saber, la de-limitación del saber" $"$.

Portanto, como a questão da soberania é, também, uma questão de conhecimento, torna-se mais compreensível a crítica avassaladora de Derrida a respeito de Agamben. À parte a imemorial separação entre biós e zoé, que Derrida absolutamente refuta, ele se empenha em demonstrar que um discurso (o de Agamben) que se atina a criticar a soberania assenta-se sobre a mesma lógica. Isso se revela na necessidade de que sente Agamben em estabelecer "primeiridades", em apontar datas e eventos fundadores, iniciativas inaugurais e acontecimentos instauradores. O esforço de Agamben é, em parte, o de trazer à luz uma 
série de informações ignoradas pela crítica de até então, de "firmas principales, firmadas por príncipes del comienzo que todo el mundo, salvo el autor supuesto, habría ignorado, de modo que, cada vez, el autor de Homo sacer sería el primero en decír quién habrá sido el primero" 56.

Para Derrida, Agamben esforça-se por ser o primeiro duas vezes: o primeiro em identificar um acontecimento fundador da modernidade e em anunciá-lo e, ao mesmo tempo, o primeiro em recordar que tal acontecimento fundante não é novo e se inscreve nos recônditos do Ocidente. Derrida refere-se, sem dúvida, à separação biós e zoé, que para Agamben arrasta-se desde um passado irrevelado e marca a cisão do homem pelo direito. "Es el primero en decirnos dos cosas en una: esto acaba de ocurrir por primera vez, ustedes no han visto nada, pero tampoco han visto, se los digo yo por primera vez, que esto data de tiempos inmemoriales" ${ }^{57}$. Para Derrida, Agamben é um soberano às avessas, um crítico autoritário da autoridade. Não é o caso de entrar nos pormenores das pendengas filosóficas que divide a ambos, mas de apontar o ponto nevrálgico da crítica de Derrida a Agamben: o princípio metodológico - metacrítica. E as escolhas metodológicas de Agamben refletem na sua elaboração teórica, invariavelmente.

O objetivo deste ensaio é o de contrastar criticamente as posições de Agamben e Bataille diante de algo que se chamou, primeiro com Benjamin, mas depois e principalmente com Flusser, de "crise da religiosidade". Sendo assim, este trabalho não pode ignorar o ensaio "Profanações", de Agamben, que nada mais faz do que dar sequência à discussão sobre a religião, embora de publicação precedente em relação aos trabalhos citados anteriormente.

O ensaio está recheado de asseverações definitivas, muitas delas duvidosas. A começar pelo protótipo escolhido por Agamben para caracterizar a situação contemporânea: o museu, "na medida em que esse termo indica simplesmente a exposição de uma impossibilidade de usar, de habitar, de fazer experiência" ${ }^{38}$. À parte a infinidade de procedimentos interativos presentes nos museus hodiernos, que caberia discutir, será mesmo que o museu é um espaço onde não é possível fazer experiência? Uma exposição já não é, em si, uma experiência, ou seja, o resultado de um esforço de montagem que está ali para ser visto, transfigurado e remontado?

O mesmo vale para o juízo conservador que emite a respeito da pornografia, na tão batida tese de que a pornografia "banaliza" o comportamento sexual do homem. Agamben afirma que a pornstar está mais interessada, ao olhar para a objetiva, no telespectador do que no seu partner. Uma pergunta a ficar sem resposta: será que a pornstar está mesmo mais preocupada com o telespectador, ou estaria ela mais preocupada com a câmera?
56. Ibidem, p. 121.

57. Ibidem, p. 385.

58. AGAMBEN, Giorgio. Profanaçōes, 2007, p. 73. 
59. Idem. O que é o contemporâneo? e outros ensaios, 2009.

60. Uma pergunta a ser respondida no futuro: a própria linguagem não opera por separação, no sentido tão conhecido de que as palavras não correspondem às coisas? A própria linguagem não teria, portanto, um aspecto religioso?

61. A esse propósito, Nancy se pergunta: "¿no debe la edad de la técnica ser comprendida en tanto que la edad del fin del sacrificio? Es decir, ¿'en tanto que la edad del fin de la transapropiación? NANCY, Jean-Luc. "Lo insacrificable", 2002, p. 76.

62. FLUSSER, Vilém.

"Coincidência incrível", 2002, p. 35.
Agamben ocupa-se da discussão a respeito da técnica, mas pouco ou nada se ocupa do funcionamento da técnica. Isso o leva a afirmações sem fundamento, tais como: "É uma experiência comum que o rosto de uma mulher que se sente olhada se torne inexpressivo", pois saber que se é olhado funciona como um "desagregador dos processos expressivos que costumeiramente animam o rosto". Pense-se em fotos antigas, por exemplo nos retratos de escritores. A baixa qualidade técnica do processo exigia um longo tempo de exposição diante da objetiva. Os cenários também eram devidamente preparados. Todas essas pessoas sabiam que estavam sendo fotografadas, e muitas delas olhavam para a objetiva. A pergunta que se impõe é: são essas fotos inexpressivas?

Para Agamben, religião é aquilo que subtrai do uso comum para transferir à outra esfera, quer se trate de coisas, lugares, animais ou pessoas. Toda religião demanda separação, e toda separação tem ou conserva em si um núcleo religioso. É por isso que identifica na palavra religio não a costumeira etimologia religare (que implica em re-ligar humano e divino), mas relegere, no sentido de cuidar para que homens e deuses se mantenham distintos. Profanar é ignorar a separação ou fazer dela um uso diferente.

Agamben adverte que se trata de resistir à apreensão pelo poder do que ele chama de "meios puros": a pornografia apreende o sexo, a propaganda apreende o defecar e a grande mídia apreende a linguagem. Vale lembrar que sua definição de dispositivo é abrangente: vai do cigarro à televisão, das ferramentas da agricultura à linguagem ${ }^{59}$. Neste sentido, é confuso ler que o "dispositivo" linguagem é apreendido pelo "dispositivo" midiático ${ }^{60}$. O que é, afinal, um dispositivo? Como os meios puros estão apreendidos, o mundo encontra-se em modo improfanável, sendo a tarefa da geração que vem profanar o improfanável ${ }^{61}$.

"A torneira é o equivalente de ídolos de épocas passadas" A partir desta quase "máxima", Vilém Flusser assinala que os instrumentos produzidos pelo homem são "obras de graça". Desde o renascimento, a separação entre homem e mundo, entre sujeito e objeto, foi estabelecida com ênfase. O homem está voltado contra a natureza (contra o mundo) e deve contra ela avançar a fim de conhecê-la, classificá-la, objetificá-la. O pensamento ocidental ideal (cartesiano) é o que unifica pensamento e coisa extensa. Para falar com Borges quando este escreve sobre a ciência, é o momento em que o mapa da cidade coincide com a própria cidade. Segundo Flusser, o homem assume o papel de "segundo Deus", e a estratégia que adota para fundir pensamento e coisa extensa é a criação de instrumentos pela via da tecnologia. Flusser afirma que o homem entra em contato com o mundo, "se realiza", através dos instrumentos. Como fica evidente, pensar os instrumentos como forma de realização do homem no mundo é diferente da ideia agambeniana de 
dispositivo. À diferença que Flusser não considera a linguagem um instrumento. Instrumento, para ele, é aplicação de técnica para a produção de objetos - tecnologia. "A transformação das coisas em instrumentos é um processo irreversível e as tentativas reacionárias de fazê-lo refluir são fadadas ao malogro"63.

Há um artigo de Flusser sobre a memória ${ }^{64}$ que calha com a discussão que se apresenta. Grosso modo, ele divide a memória humana em duas: herdada, transmitida geneticamente ao logo da "evolução", e adquirida, que se dá via cultura. É a memória adquirida que faz do homem homem, ou seja, a capacidade de adquirir informações, processá-las e de reenviá-las aos seus pares. Em tempos passados, o "local" de processamento e memorização era o mesmo, o cérebro. A distinção entre hardware e softwware ainda não se dava.

A invenção das assim chamadas "memórias artificiais" problematiza a memória humana em dois sentidos: radicaliza os gestos de manipulação da informação, por um lado, e transforma o processo de armazenamento e impressão, por outro. A memória artificial faz com que o homem, que ainda manipula informação em seu cérebro, passe a ter o hábito de armazená-la fora dele, na máquina. Esse desdobramento "desideologizante" ${ }^{65}$ faz ruir a ideia da memória concebida enquanto um "algo", e permite tomá-la enquanto um "como". O homem assume "distância crítica” em relação à própria memória, podendo observar "de fora" ${ }^{\$ 6}$ como ela se forma. Isso lhe permite emancipar-se da tarefa de acumular informações e dedicar-se quase que exclusivamente à tarefa de processar informações. Se esse processo se desenvolve nesses termos, então o resultado é um ganho de criatividade, e não uma perda a ser lamentada - automatização da vida ou mecanização de um processo natural.

Para voltar à Agamben, a preocupação aqui não é se a memória artificial apreende o "meio puro" memória, mas é o de pensar num ganho criativo que pode ocorrer caso o agir humano seja mantido no âmbito em que é imprescindível: no manipular, processar e selecionar informações. Flusser acredita que a memória artificial possibilita ao homem "des-reificar" a memória de "entidades ideológicas" ${ }^{67}$ tais como alma, imortalidade e Deus. Mas isso não implica:

como pode parecer, profanação [grifo meu] (dessacralização) da dignidade humana. Pelo contrário, a capacidade especificamente humana para processar dados adquiridos e armazená-los (a capacidade de opor-se à natureza física e biológica) passa a ser ainda mais misteriosa. De maneira que pode ser dito, um tanto paradoxalmente, que a invenção das memórias eletrônicas acentua ainda mais o mistério que é o ser humano, ao proporcionar-lhe a distância crítica para com a sua própria humanidade. A desideologização dos conceitos ontológicos e teológicos tradicionais não
63. Idem. "Em louvor do espanto", 2002, p. 95.

64. Idem. "Memória", 1998, p. $177-185$.

65. Ibidem, p. 183.

66. Ibidem, p. 183

67. Ibidem, p. 184. 
Em outro momento se disse que um dos sintomas do que se chamou "crise da religiosidade" era o enfraquecer da confiança nas religiões tradicionais e na crença em Deus. Mas, com Flusser, é possível pensar que o mundo não está, mesmo com o declínio da religiosidade tradicional e com o avanço do progresso técnico, improfanável. Com Flusser, o caso também não é o de abolir a separação criada por instrumentos ("dispositivos") ou dela fazer um uso novo, movimento esse que Agamben chama de "profanação". Como no exemplo da memória, o advento da memória eletrônica faz com o que homem esqueça, de uma vez por todas, como funciona a própria memória. Em termos religiosos, a memória eletrônica não profana nem improfana a memória humana, mas a sacraliza no sentido de mantê-la enigmática. Caixa preta é isso: hardware impenetrável, software manipulável com facilidade. Instrumentos não deixam necessariamente o mundo menos opaco. Se para Flusser os instrumentos são "obras de graça", cabe encontrar a graça que eles têm.

\section{Referências}

AGAMBEN, Giorgio. Altíssima Pobreza: regras monásticas e formas de vida. Tradução de Selvino José Assmann. São Paulo: Boitempo, 2014.

. "Bataille e o paradoxo da soberania". outra travessia. n. 5, 2005, p. 91-94.

Homo Sacer: o poder soberano e a vida nua. Tradução de Henrique Burigo. Belo Horizonte: UFMG, 2010.

Opus Dei: arqueologia do ofício. Tradução de Daniel

Arruda Nascimento. São Paulo: Boitempo, 2013.

O que é o contemporâneo? e outros ensaios. Tradução de Vinícius Nicastro Honesko. Chapecó: Argos, 2009.

Profanaçoes. Tradução de Selvino José Assmann. São Paulo: Boitempo, 2007.

ANTELO, Raul. "O lugar do erotismo". Prefácio. In: BATAILLE, Georges. O erotismo. Tradução de Fernando Scheibe. Belo Horizonte: Autêntica, 2014, p. 19-25.

BATAILLE, Georges. A experiência interior. Seguido de Método de Meditação e Postscriptum 1953. Suma Ateológica - Vol. I.

Tradução de Fernando Scheibe. Belo Horizonte: Autêntica, 2016, no prelo. 
. "El erotismo o el cuestionamiento del ser". Tradução de Silvio Mattoni. In: ___. La felicidad, el erotismo y la literatura. Buenos Aires: Adriana Hidalgo, 2001, p. 338-363. “¿Es útil la literatura?”. Tradução de Silvio Mattoni.

In:__. La felicidad, el erotismo y la literatura. Buenos Aires: Adriana Hidalgo, 2001, p. 17-19.

"La guerra y la filosofía del sagrado". Tradução de Silvio Mattoni. In: ___. La felicidad, el erotismo y la literatura. Buenos Aires: Adriana Hidalgo, 2001, p. 157-171.

- Lo que entiendo por soberanía. Tradução de Pilar Sánchez Orozco e Antonio Campillo. Barcelona: Paidós, 1996. "No-saber, risa y lágrimas". Tradução de Ignacio Díaz de la Serna. In: ___ La oscuridad no miente. Madrid: Santillana, 2002, p. 113-134.

O culpado. Seguido de A Aleluia. Suma Ateológica - Vol

II. Tradução de Fernando Scheibe. Belo Horizonte: Autêntica, 2016, no prelo.

- O erotismo. Tradução de Fernando Scheibe. Belo

Horizonte: Autêntica, 2013.

Sobre Nietzsche: vontade de chance. Suma Ateológica - Vol

III. Tradução de Fernando Scheibe. Belo Horizonte: Autêntica, 2016, no prelo.

BENJAMIN, Walter. "Experiência e pobreza". In: Magia e técnica, arte e política: ensaios sobre literatura e bistória da cultura. Tradução de Sergio Paulo Rouanet. São Paulo: Brasiliense, 1994, p. 114-119.

O capitalismo como religião. Tradução de Nélio Schneider e Renato Ribeiro Pompeu. São Paulo: Boitempo, 2013. "O narrador". In: Magia e técnica, arte e política: ensaios sobre literatura e história da cultura. Tradução de Sergio Paulo Rouanet. São Paulo: Brasiliense, 1994, p. 197-221.

COCCIA, Emanuele. "O mito da biografia ou sobre a impossibilidade da teologia política". outra travessia. n. 12, 2012, p. 7-21.

DERRIDA, Jacques. Seminario La bestia y el soberano: volumen 2001-2002. Tradução de Cristina de Peretti e Delmiro Rocha. Buenos Aires: Manantial, 2010.

ELIADE, Mircea. O sagrado e o profano: a essência das religiōes. Tradução de Rogério Fernandes. São Paulo: Martins Fontes, 2008. 
FLUSSER, Vilém. “Coincidência incrível". In: Da

religiosidade: literatura e o senso de realidade. São Paulo: Escrituras, 2002, p. 31-36.

"Da religiosidade". In: - Da religiosidade: literatura e o senso de realidade. São Paulo: Escrituras, 2002, p. 15-21. "Em louvor do espanto". In: Da religiosidade:

literatura e o senso de realidade. São Paulo: Escrituras, 2002, p. 91-96. "Ensaios". In: Ficções filosóficas. São Paulo: USP, 1998, p. 93-97.

.Gestos. São Paulo: Annablume, 2014. "Livros". In: . Fições filosóficas. São Paulo: USP, 1998, p. 123-128.

"Memória". In: . Fiç̧ões filosóficas. São Paulo: USP, 1998 , p. $177-185$.

. Ser judeu. São Paulo: Annablume, 2014.

. “Um mundo fabuloso". In: . Ficções filosóficas. São Paulo: USP, 1998, p. 23-27.

. Vampyroteuthis Infernalis. São Paulo: Annablume, 2011.

NANCY, Jean-Luc. "Lo insacrificable”. Tradução de Juan Carlos Moreno Romo. In: . Un pensamiento finito.

Barcelona: Anthropos, 2002, p. 47-82. 